\author{
Włodzimierz Bednarek \\ dr hab. inż. \\ Politechnika Poznańska Wydział Budownictwa i Inżynierii Środowiska, \\ Zakład Budowy Mostów i Dróg Kolejowych \\ włodzimierz.bednarek@put.poznan.pl
}

DOI: 10.35117/A_ENG_16_11_05

\title{
Static analysis of chosen imperfections of rail subgrade on additional rail deflection of contactless track
}

\begin{abstract}
In the paper, the chosen imperfections of railway subgrade causing additional rail deflections in contactless tracks were analysed. For such imperfections the following problems were selected: contactless work of railway track resting on the local uneven subgrade; loss of contact between track and subgrade; influence of variable compressive force on the length of contactless track; change in support stiffness on the deflection of contactless rail track. The presented static analysis has shown the importance of unfavourable influence of selected factors on work of contactless rail track (e.g. increase in the length of contact loss between track and subgrade or arising an additional deflections and stresses). A special attention was paid on such imperfections, apart from deflections and stresses cause among other things a disturbance of translational motion of rolling stock due to these imperfections. In the paper, a special accent was laid on visualization the influence of selected factors on work of contactless rail track, giving in many places in the paper the proper publications, in which the complete procedures of theoretical analysis of the considered problems are shown in the comprehensive way.
\end{abstract}

Keywords: contactless track; imperfections in track; non-homogeneity of rail subgrade; additional rail deflections

\section{Introduction}

The state of the railway track as well as its shape and position, described by the geometrical parameters, is gradually changed during exploitation [2]. The resulting changes in the geometric position of the path followed mainly due to the load of vehicles, change its support and work performed in the track (raising track, ballast cleaning). The cause of the track deformation is the diversity of characteristics of the track support $[2,3,4,9,10]$ in its various sections arising as a result of such, e.g. uneven subsidence of ballast during exploitation, increased strain especially in the area of the so-called weak subgrade (Fig. 1) or the presence of swelling soil in the subgrade.
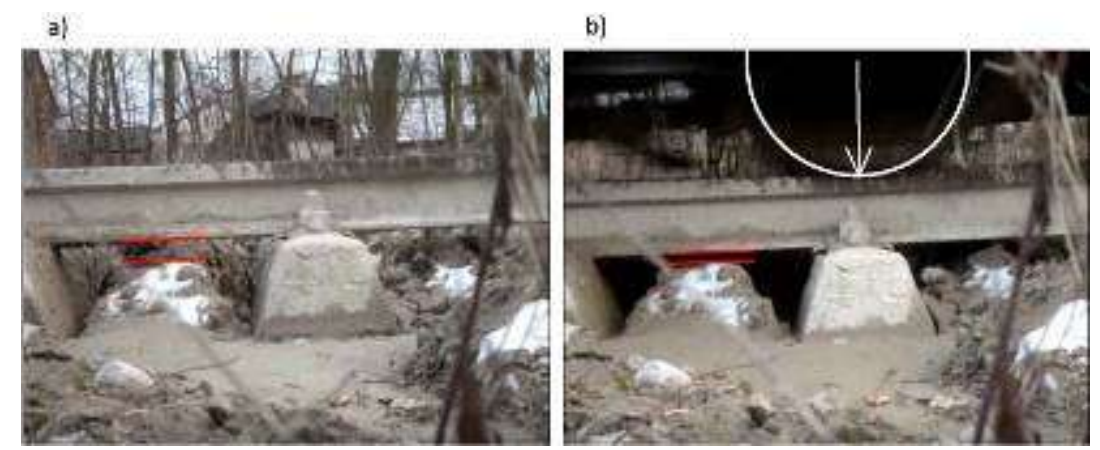

1. Deflection of rail track in the site of weak subgrade; a) the track without load, b) the track under load of rolling stock (visible reduction in gaps under sleeper) [22] 
As a result of ground unevenness, these factors are responsible for the formation of different types of contact between sleeper and ballast layer. Track stiffness in the unloaded condition (without pressure from the vehicle) causes that sleepers rest in varying degrees on the ballast. In the worst case, it may occur the complete lack of contact of the sleeper with the ballast (which can be clearly seen in Fig. 1). Such areas of the lack of contact with the ground ballast are particularly dangerous for the stability of contactless track in summer during periods of longitudinal compressive forces.

In the unloaded track it is difficult to assess the impact of such local unevenness for the work of the railway track in the vertical plane. Changing way of support of the track can be described only in a loaded track, upon the application of pressure originating for example by locomotive axles. The resulting heterogeneity of rail subgrade is a source of additional stress and deflection of the rail under usable load $[5,9,10,18]$. Imperfections analysed in the paper arising during exploitation of track [6] are random and unintentional.

\section{Static analysis of contactless railway track resting on the local uneven ground}

This section considers the contactless railway track resting on three consecutive uneven grounds as shown in Fig. 2a [5,8]. The analysis was carried out on the track working on oneparameter elastic subgrade with unilateral and bilateral ties $[5,12,13,19,20]$. Fig. 2 b shows results of calculation for the three ground irregularities. Due to the symmetry of the system, it is considered the right side of uneven subgrade - Fig. 2c [5].

a)

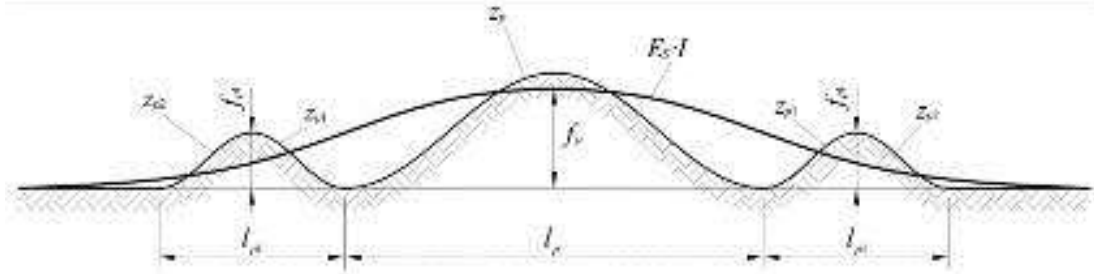

b)

$$
\begin{aligned}
& z_{p}=\frac{f_{p}}{2} \cdot\left[1-\cos 2 \cdot \pi \cdot\left(0,5+\frac{x}{l_{p}}\right)\right] \\
& z_{p_{1}}=\frac{f_{p_{1}}}{2} \cdot\left[1-\cos \cdot\left(\frac{2 \cdot \pi \cdot x_{p_{2}}}{l_{p_{1}}}\right)\right] \\
& z_{p_{2}}=\frac{f_{p_{1}}}{2} \cdot\left[1-\cos 2 \cdot \pi \cdot\left(0,5+\frac{x_{p_{2}}}{l_{p_{1}}}\right)\right]
\end{aligned}
$$

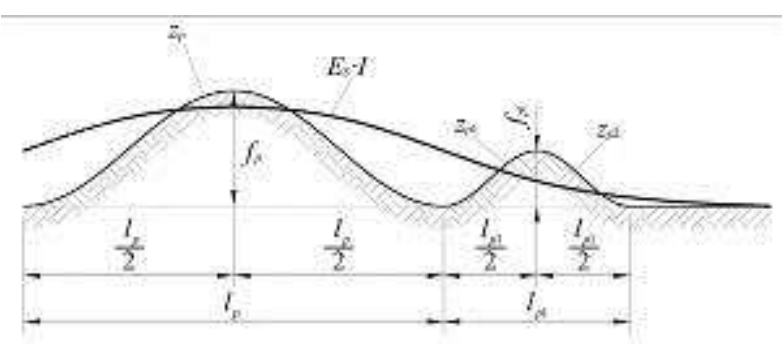

c)

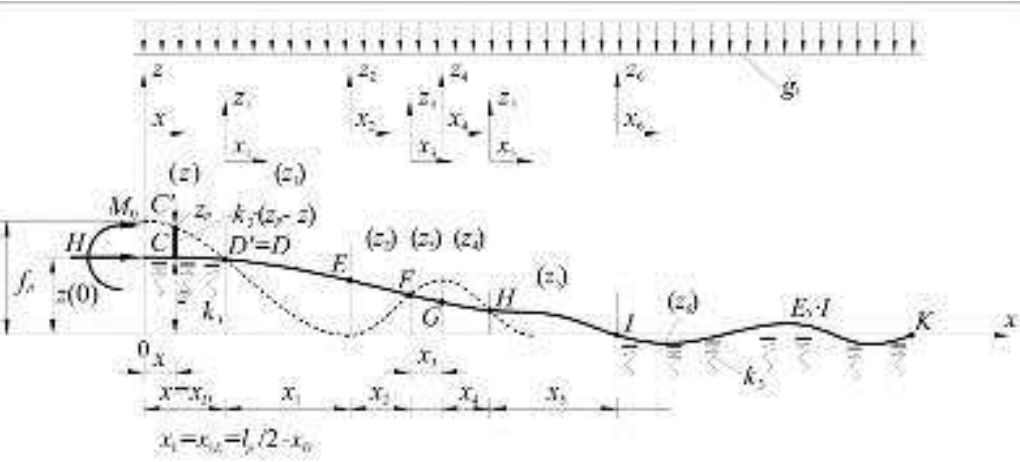

2. Schema of calculation of the three unevenness of ground; a) scheme of three ground unevenness, b) assumed ground unevenness; c) calculation scheme with local systems 
Disregarding way of thinking contained in [5], the impact of such emerging unevenness was illustrated in calculation examples. The following parameters were adopted: the track with $60 \mathrm{E} 1$ rails, wooden sleepers, $E_{S} \cdot I=12,831 \mathrm{MNm}^{2}$ (track stiffness), $g_{t}=0,0026 \mathrm{MN} / \mathrm{m}$ (rail weight), $k=41,0 M P a$ (coefficient of ballast ground), $H=1,837 M N$ (compressive strength), and ground unevenness (Fig. 2):

I case (single ground unevenness)

$1^{\circ} f_{p}=0,02[m] ; l_{p}=14,0[m], R_{P}=\frac{l_{P}^{2}}{2 \cdot \pi^{2} \cdot f_{P}}=496,47 m$ (middle unevenness),

$\mathbf{2}^{\circ}$ the lack of side unevenness, then $f_{p_{1}}=0$.

The analysis can describe the behaviour of the contactless track resting on single ground unevenness. Characteristic cut sections of the track are as follows:

$x_{D}=2,8759 m, x_{1 E}=4,6387 m$ (where: parameters $x_{D}$ and $x_{1 E}$ are shown in Fig. 2.1c).

II case (triple ground unevenness)

$$
\begin{aligned}
& \mathbf{1}^{\circ} f_{p 1}=0,0018[m] ; l_{p 1}=6,0[\mathrm{~m}], R_{P 1}=\frac{l_{P 1}^{2}}{2 \cdot \pi^{2} \cdot f_{P 1}}=1013,21 \mathrm{~m} \text { (side unevenness), } \\
& \mathbf{2}^{\circ} f_{p}=0,02[\mathrm{~m}] ; l_{p}=14,0[\mathrm{~m}] \text { (middle unevenness). }
\end{aligned}
$$

The analysis can describe the behaviour of the contactless track resting on triple ground unevenness. Characteristic cut sections of the track are as follows:

$$
\begin{aligned}
& x=x_{D}=3,12104[\mathrm{~m}] ; x_{1}=x_{E}=3,87896[\mathrm{~m}] \rightarrow x_{D}+x_{E}=\frac{l_{P}}{2}=7,0[\mathrm{~m}] ; \\
& x_{2}=x_{F}=1,40435[\mathrm{~m}] ; x_{3}=x_{G}=1,65415[\mathrm{~m}] ; x_{4}=x_{H}=1,18464[\mathrm{~m}] ; x_{5}=x_{I}=2,60686[\mathrm{~m}] .
\end{aligned}
$$

The results of these calculations are presented in Fig. 3.

As seen in Fig. 3, unevenness assumed in the calculations causes a change in the track support. A single unevenness in the ground causes that the length of the segment in the track losses contact with the ground is $4.64 \mathrm{~m}$. However, in the case of three ground unevenness there is an increase in the length of lack of track contact with the ground to the value of up to $5.283 \mathrm{~m}$, which affects especially its work in a horizontal plane under high temperatures. In addition, deformable ballast substrate and railway track causes, e.g. a progressive disorder of the railway rolling stock as a result of emerging unevenness. During the passage of the wheels through the vertical geometric unevenness, rotational movement of the wheel is disturbed, resulting in lowering the efficiency of the traction wheels and influencing the extension of the road wheel centre [14]. The concept of traction wheel efficiency is defined as the practical utilization of adhesion, resulting from the static pressure during exploitation [14]. On the basis of theoretical calculations [14], it was found that when motion is conducted with the speed of $30 \mathrm{~m} / \mathrm{s}(108 \mathrm{~km} / \mathrm{h})$, the traction efficiency is reduced by $50 \%$ when the amplitude of the unevenness of the track exceeds $7 \mathrm{~mm}$ [14] in the length of 2 [m]. Train movement on unevenness in the track can greatly reduce the efficiency of the drive and braking. Disorders of the rotational movement of the wheel while driving on an uneven path at a fixed speed of movement of the wheel centre along the straight track are shown in Fig. 4 (the detail A). 
a)

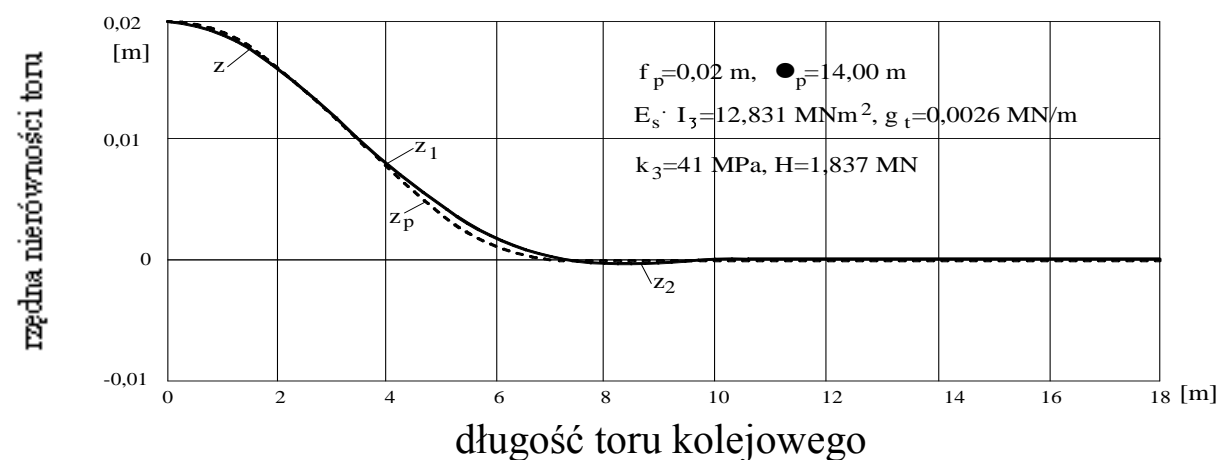

b)

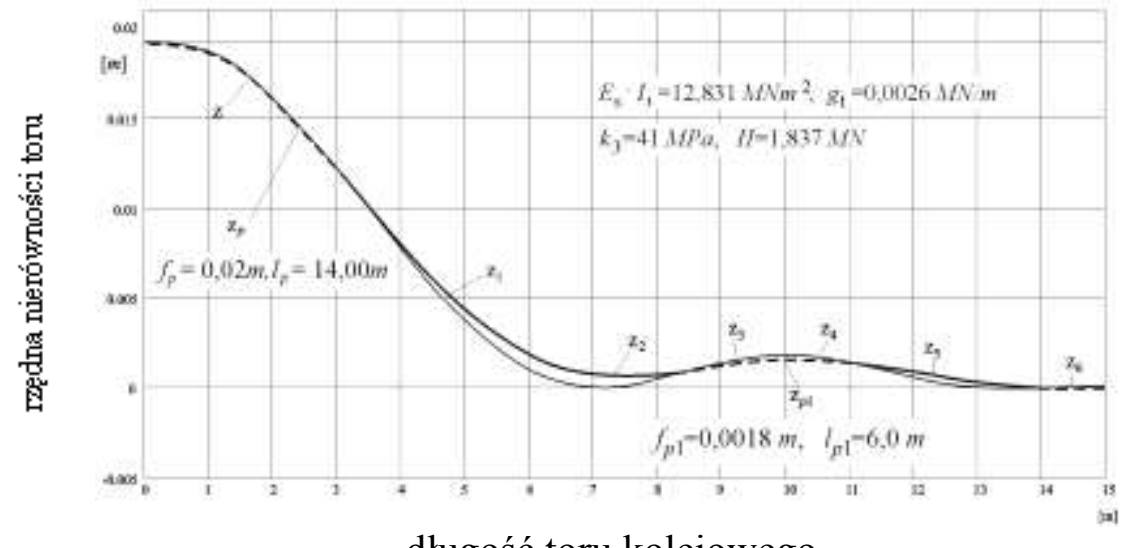

długość toru kolejowego

3. The line of track deflection on local uneven ground [5]:

a) single ground unevenness: $f_{P}=0,02 \mathrm{~m}$ i $l_{P}=14,0 \mathrm{~m}$ (middle unevenness),

b) triple ground unevenness: $f_{P}=0,02 \mathrm{~m}$ i $l_{P}=14,0 \mathrm{~m}$ (middle unevenness) oraz $f_{P}=0,0018 \mathrm{~m}$ i $l_{P}=6,0 \mathrm{~m}$ (side unevenness)

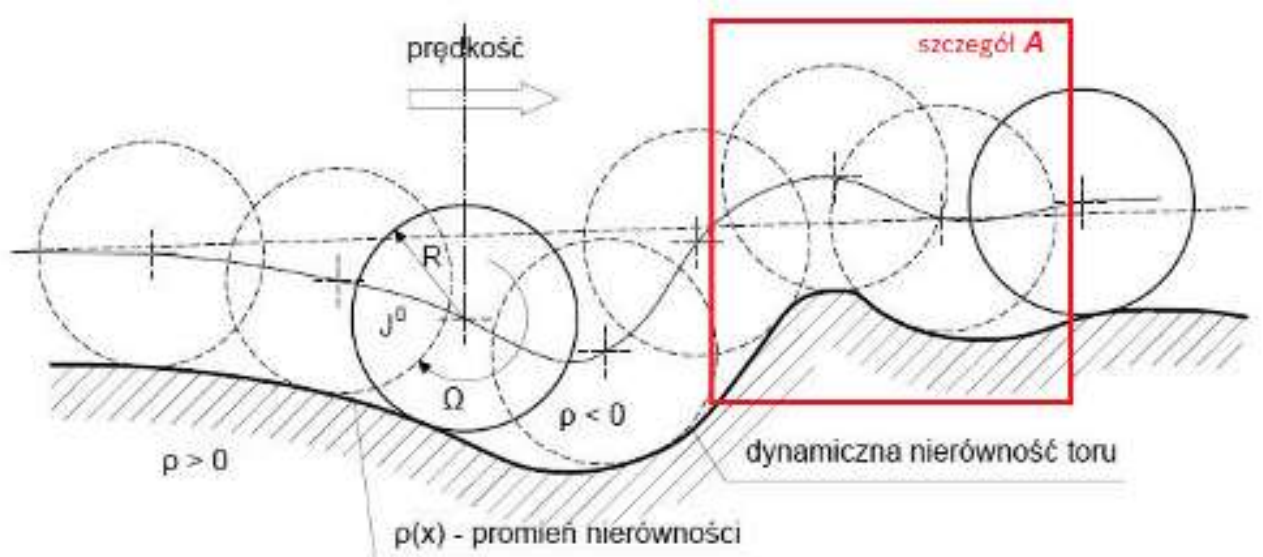

4. Disorders of rotational movement of the wheel while driving on an track uneven along a straight path [14]

\section{Selected imperfections causing change in operating conditions of track elements}

In the real railway track, it comes to the formation of various forms of changes in their work conditions for its individual elements. These include among other:

- track as the beam resting on the substrate [5.15], 
- variable value of the compressive axial force in the railway track [5],

- variable stiffness of railway track element along its length (e.g. sleeper) [5],

- variable values of parameters of the substrate [5].

Frequent changes in support stiffness due to e.g. the occurrence of ground soil with different characteristics $[1,11,17]$, the thickness of ballast or type of pavement structure affect, among others, additional deflection of rail. To determine the effect of lack of contact between the ground and track on the rail deflection, we analysed the stretch of track in the immediate area of the load by the finite element [5,7]. The calculations were performed for concentrated load $\mathrm{P}$ of $100[\mathrm{kN}]$ applied in the middle of the section (on the basis of the analyses we assumed this case for the most favourable), showing the impact of extending the zone with no contact on the maximum deflection of the rail.

Calculations were carried out to study the relationship between the length of the track section on which there is no contact between the sleepers and the ballast, and the maximum deflections of the rail. For analysis, we used the 100-element calculation scheme, resulting in the division of $15 \mathrm{~m}$ section on track elements with the length of $15 \mathrm{~cm}$. The calculations were done for rails 60E1, 49E1 and the reference rail (having a higher rigidity, for example, rail R75) loaded with concentrated force in the middle of the section, by adopting the following data:

$-E=210[\mathrm{GPa}]$,

$-I_{60 \mathrm{E} 1}=3038,3^{*} 10^{-8}\left[\mathrm{~m}^{4}\right], I_{49 \mathrm{E} 1}=1816^{*} 10^{-8}\left[\mathrm{~m}^{4}\right][16], I_{\mathrm{por}}=4597 * 10^{-8}\left[\mathrm{~m}^{4}\right]$ (np. Rail of type R75)

$-E I_{\mathrm{UIC} 60}=6,38\left[\mathrm{MNm}^{2}\right], E I_{49 \mathrm{E} 1}=3,814\left[\mathrm{MNm}^{2}\right], E I_{\mathrm{por}}=9,65\left[\mathrm{MNm}^{2}\right]$

- and concentrated force $P=100[\mathrm{kN}]$.

No contact between the sleepers and the ballast has been included in the calculation by adopting susceptibility coefficient of even ground $C=0\left[\mathrm{MN} / \mathrm{m}^{3}\right]$ in this section. For the rest of the path, we assumed the constant coefficient of substrate susceptibility $[1,5,22]$ :

$-C=100\left[\mathrm{MN} / \mathrm{m}^{3}\right]$,

- and $d$ - axial spacing between the sleepers (assumed as $60 \mathrm{~cm}$ ).

Calculations were carried out for six different lengths of zones without contact, extending successively the length of the zone from $\mathrm{d} / 2$, i.e. $30 \mathrm{~cm}$ to the value of up to $3 *$ d, which is 180 $\mathrm{cm}$, as shown in Fig. 5: 

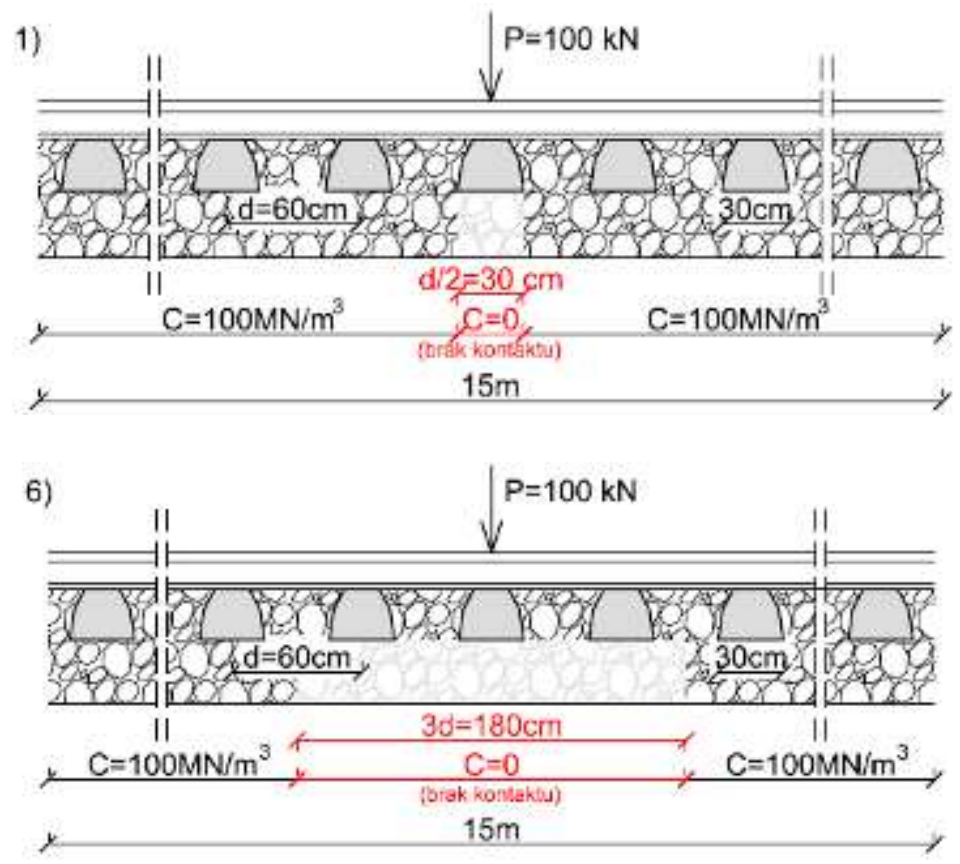

5. Assumed extreme computing cases (no contact from $\mathrm{d} / 2$ to $3 \mathrm{~d}$, that is from $30 \mathrm{~cm}$ to 180 $\mathrm{cm})[22]$ (the so-called hanging sleeper/sleepers effect)

The results of the calculations for the analysed rails are summarized in Table 1. Fig. 6 shows a comparison of the maximum deflection of analysed computing schemes.

Tab. 1. Values of the maximum deflection of analysed rails depending on the length of the zone with no contact

\begin{tabular}{|c|c|c|c|c|}
\hline $\begin{array}{c}\text { Scheme } \\
\text { number }\end{array}$ & $\begin{array}{c}\text { Length of } \\
\text { no-contact } \\
\text { zone }[\mathrm{cm}]\end{array}$ & $\begin{array}{c}\text { The maximum } \\
\text { deflection of } \\
\text { reference rail } \\
{[\mathrm{mm}]}\end{array}$ & $\begin{array}{c}\text { The maximum } \\
\text { deflection of } \\
\text { rail 60E1 } \\
{[\mathrm{mm}]}\end{array}$ & $\begin{array}{c}\text { The maximum } \\
\text { deflection of } \\
\text { rail 49E1 } \\
{[\mathrm{mm}]}\end{array}$ \\
\hline 0 & 0 & 1.794 & 1.987 & 2.262 \\
\hline 1 & $30(\mathrm{~d} / 2)$ & 2.070 & 2.329 & 2.714 \\
\hline 2 & $60\left(1^{*} \mathrm{~d}\right)$ & 2.419 & 2.773 & 3.319 \\
\hline 3 & $90\left(1,5^{*} \mathrm{~d}\right)$ & 2.850 & 3.332 & 4.098 \\
\hline 4 & $120\left(2^{*} \mathrm{~d}\right)$ & 3.373 & 4.018 & 5.074 \\
\hline 5 & $150\left(2,5^{*} \mathrm{~d}\right)$ & 3.996 & 4.845 & 6.268 \\
\hline 6 & $180\left(3^{*} \mathrm{~d}\right)$ & 4.727 & 5.826 & 7.703 \\
\hline
\end{tabular}


a)

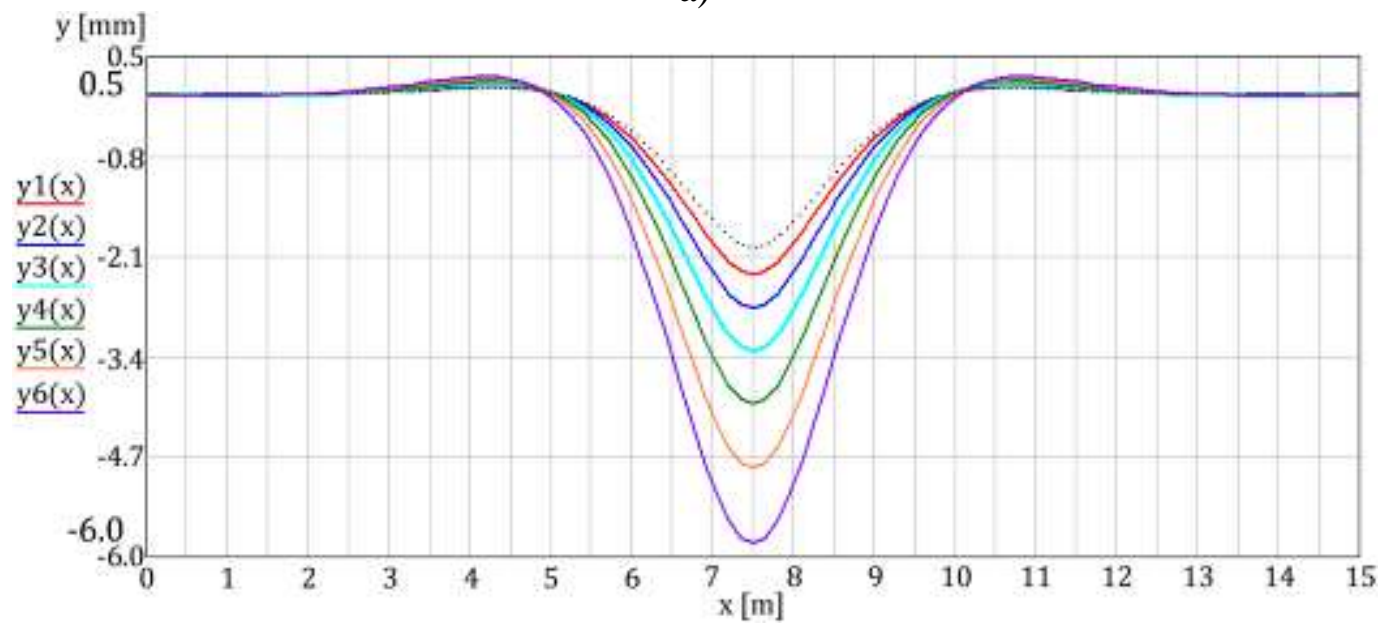

b)

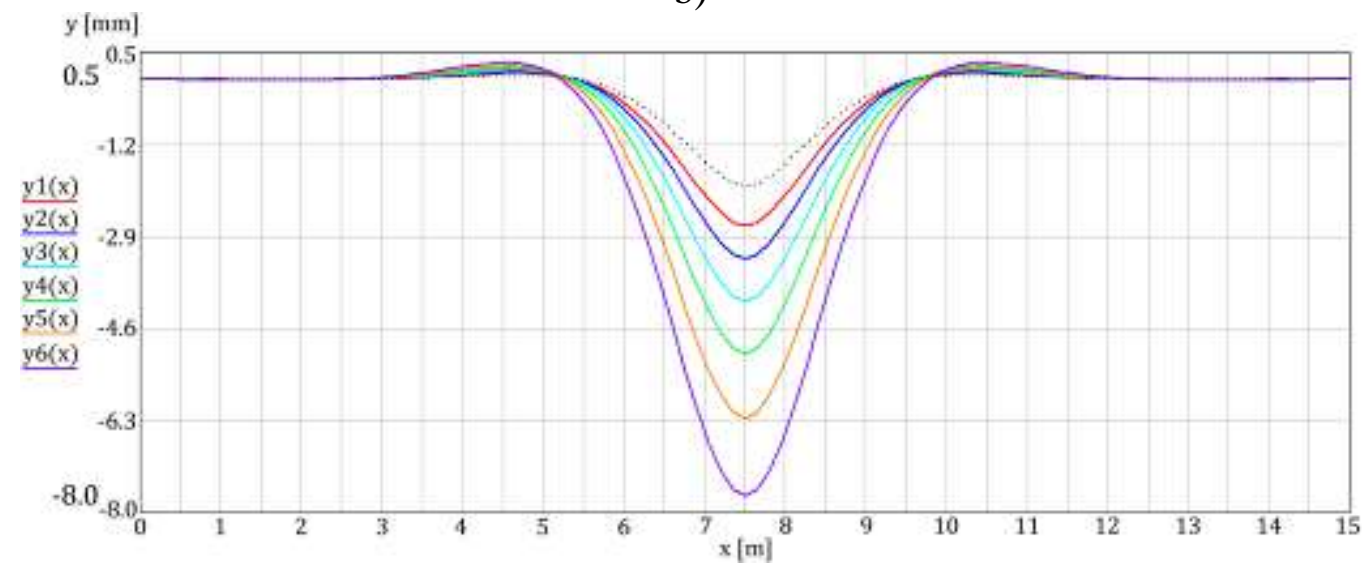

c)

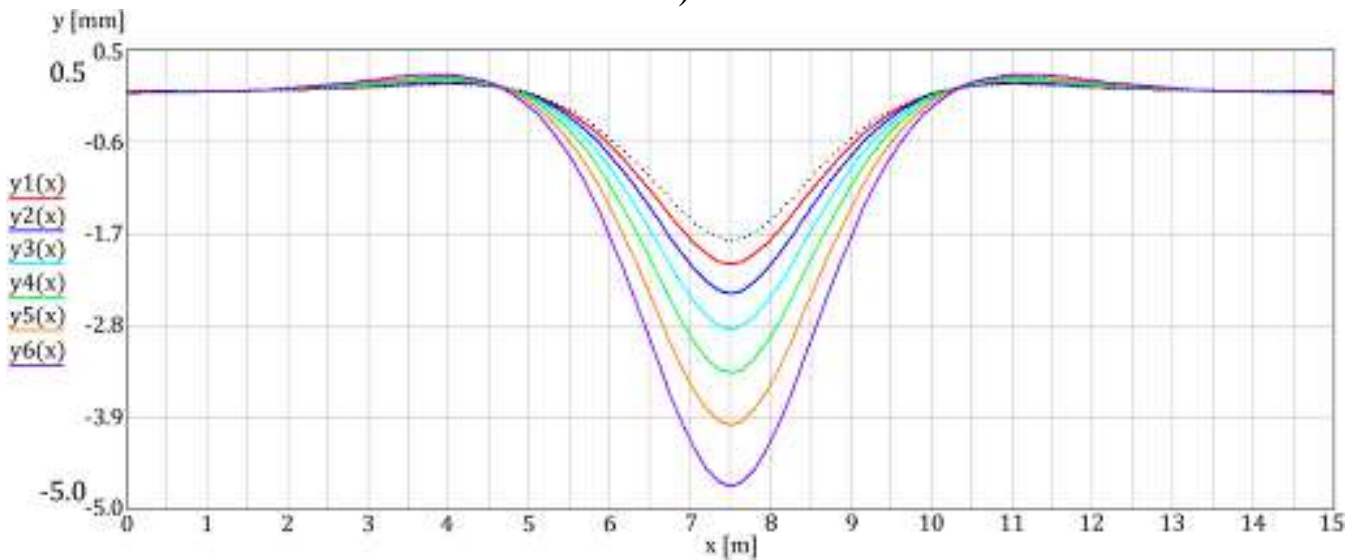

6. Comparison of the maximum deflections of the rail depending on the length of the zone with no contact for analysed rails [22]

a) rail 60E1; b) rail 49E1; c) reference rail (designations as in Table. 3.1, the comparative value for scheme $O$ is marked by a dotted line)

On the basis of Fig. 6, and the maximum deflection contained in Table 1, we found that the length of the zone with no contact between the track and the ballast has a significant impact on the maximum deflection of the rail.

Received values of the maximum deflection of the reference rail (summarized in Table 1.) are smaller than the designated deflection for rail 49E1 and $60 \mathrm{E} 1$. The maximum deflection is $4.727 \mathrm{~mm}$ for the no contact zone with the length of $180 \mathrm{~cm}$, which is about $61 \%$ 
of the maximum deflection of the rail 49E1, and about $81 \%$ of the maximum deflection of the rail $60 \mathrm{E} 1$. The maximum $180 \mathrm{~cm}$ deflection in the case of absence of the contact zone is greater by up to about $163 \%$ of the deflection of the rail in the section with uniform stiffness of the substrate, which is $1.794 \mathrm{~mm}$. On the basis of the calculation shown in Fig. 6, it was found that the maximum deflection of the rail is for the rail 49E1. Therefore, the stiffness of the rail EI affects directly the resulting deflections of rail. The maximum deflection of the rails, regardless of their types, increases with the enlargement of the zone with no contact between the track and the ballast. During the computational analysis we also determined the additional deflection of rails $\left(y_{d}\right)$ that arise in places where the contact is lost. Their values are summarized in Table. 2.

Tab. 2. Values of additional deflection of rails $y_{d}$ depending on the type and length of the zone with no contact

\begin{tabular}{|c|c|c|c|c|}
\hline \multirow{2}{*}{$\begin{array}{l}\text { Scheme } \\
\text { number }\end{array}$} & \multirow{2}{*}{$\begin{array}{l}\text { Length of no- } \\
\text { contact zone } \\
\end{array}$} & \multicolumn{3}{|c|}{ Additional deflection of rail [mm] } \\
\cline { 3 - 5 } & $\mathrm{cm}]$ & $49 \mathrm{E} 1$ & $60 \mathrm{E} 1$ & $\begin{array}{c}\text { The reference } \\
\text { rail }\end{array}$ \\
\hline $\mathbf{0}$ & 0 & 0 & 0 & 0 \\
\hline $\mathbf{1}$ & 30 & 0,452 & 0,342 & 0,276 \\
\hline $\mathbf{2}$ & 60 & 1,057 & 0,786 & 0,625 \\
\hline $\mathbf{3}$ & 90 & 1,836 & 1,345 & 1,056 \\
\hline $\mathbf{4}$ & 120 & 2,812 & 2,031 & 1,579 \\
\hline $\mathbf{5}$ & 150 & 4,006 & 2,858 & 2,202 \\
\hline $\mathbf{6}$ & 180 & 5,441 & 3,839 & 2,933 \\
\hline
\end{tabular}

The largest additional rail deflection was recorded for rails 49E1. Changing the rail 49E1 to the reference rail will reduce the additional rail deflection for the longest analysed zone without contact by $46 \%$, while the change for the rail of type $60 \mathrm{E} 1$ will give about $30 \%$ reduction in the additional rail deflection.

Therefore, for further analysis we selected the rail of type 49E1. The additional rail deflection is affected by the variable value of the compressive axial force in the rail of contactless railway track.

Fig. 7 shows an example of a deflection of a long, contactless rail track with rails 49E1 resting on the elastic one- and two-parameter ground, calculated by finite element method [5,7,22]. It assumes no contact of the track with the ground in the central zone along the length of $4 \cdot a$, where $a$ the spacing of the sleepers (it was assumed $a=0.65 \mathrm{~m}$ ). The following data were assumed:

- track with rails of type 49E1, $E \cdot I=7,64 M N m^{2}$ (track stiffness),

$-g_{t}=0,0026 M N / m$ (track weight),

$-k_{1}^{2}=26,605 \mathrm{MPa}$ (coefficient of ballast ground),

$-k_{2}^{2}=0 M N$ (for one-parameter ground),

$-k_{2}^{2}=2,6605 M N$ (for two-parameter ground). 


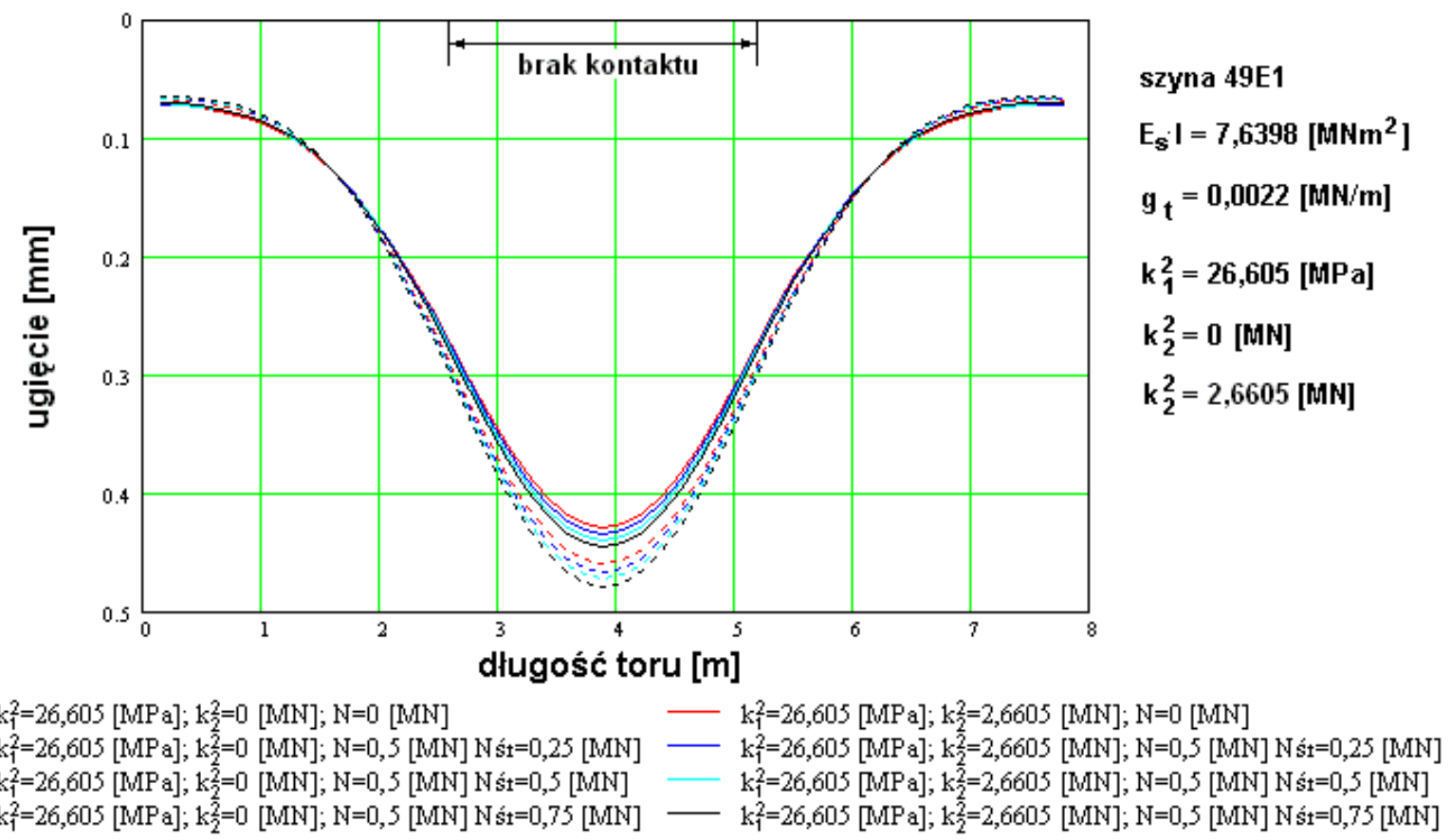

7. Fragment of infinitely long contactless track with the rails 49E1, resting on the elastic oneand two-parameter substrate in the absence of its contact with the ground in the central zone along the length of $2.6 \mathrm{~m}$ (numerical analysis) [5]

In Fig. 7, no contact between the track and ground is on the stretch between the sections $2.6 \mathrm{~m}$ and $5.2 \mathrm{~m}$ on the length of railway track. It was also included the impact of a compressive axial force on the track. Four variants of changes in compressive strength was assumed:

1) the lack of longitudinal force in the track,

2) force at the beginning of the track section is set to $0.5[\mathrm{MN}]$, it decreases linearly at the centre of the track to $0.25[\mathrm{MN}]$ and then again increases linearly to the end of the track to $0.5[\mathrm{MN}]$,

3) constant longitudinal force in the track of $0,5[\mathrm{MN}]$,

4) force at the beginning of the track section is set to $0.5[\mathrm{MN}]$, it increases linearly at the centre of the track to $0.75[\mathrm{MN}]$ and then decreases linearly back to the end of the track to $0.5[\mathrm{MN}]$.

As shown in Fig. 7, the deflection of the track is greater for the one-parameter substrate. It increases with the growth of axial force affecting the railway track. The biggest deflection value was obtained for the fourth variant of change in the longitudinal force (dotted black line). Similarly to the track for two-parameter substrate, the biggest deflection value was obtained for the fourth variant of change in the longitudinal force (continuous black line), which can be explained by the greatest value of compressive force in this case.

The impact of changes in the stiffness of the rail support in the surrounding of the contactless zone on the rail deflection

In the real railway track, in the immediate vicinity of the zone with no contact, there is a change in the stiffness of the substrate. The impact of local change in the rigidity of the track support in the immediate vicinity of the zone with no contact on the rail deflection was made for rail 60E1. 
The calculation were based on the scheme (shown in Fig. 8), in which no contact between the track and the ballast is in the length of $\mathrm{d}=60 \mathrm{~cm}$. The calculations assume two cases of local changes in the stiffness of the support track:

- increase in the susceptibility of the substrate $C$ from $100\left[\mathrm{MN} / \mathrm{m}^{3}\right]$ to $120\left[\mathrm{MN} / \mathrm{m}^{3}\right]$,

- decrease in the susceptibility of the substrate $C$ from $100\left[\mathrm{MN} / \mathrm{m}^{3}\right]$ to value $C=80$ $\left[\mathrm{MN} / \mathrm{m}^{3}\right]$.

The local changes of the susceptibility of the substrate was assumed on the $15 \mathrm{~cm}$ and $30 \mathrm{~cm}$ sections. Calculation schemes are shown in Fig. 8.
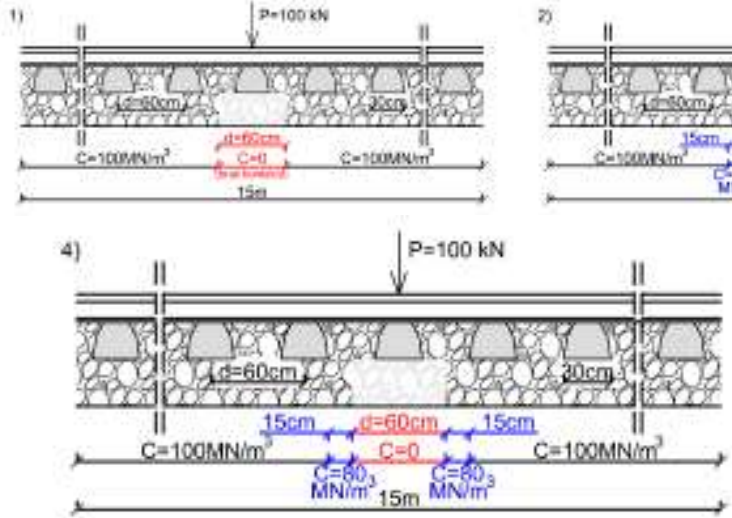
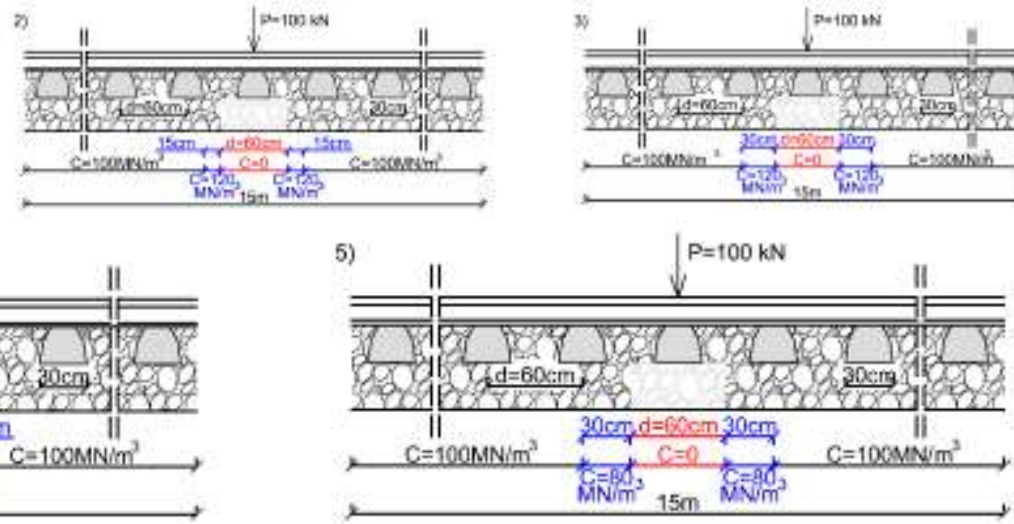

8. Computational schemes of local changes in the stiffness on the section adjacent to the zone with no contact

The results of the calculations are presented in Table 3 and in Fig. 9.

Tab. 3. The values of the maximum deflection of the rail 60E1, depending on the stiffness of the support in the section adjacent to the zone with no contact

\begin{tabular}{|c|c|c|c|c|}
\hline $\begin{array}{c}\text { Scheme } \\
\text { number }\end{array}$ & $\begin{array}{c}\text { Length of } \\
\text { no-contact } \\
\text { zone }[\mathrm{cm}]\end{array}$ & $\begin{array}{c}\text { Substrate } \\
\text { susceptibility on the } \\
\text { adjacent section } \\
{\left[\mathrm{MN} / \mathrm{m}^{3}\right]}\end{array}$ & $\begin{array}{c}\text { Length of } \\
\text { changed section } \\
{[\mathrm{cm}]}\end{array}$ & $\begin{array}{c}\text { Rail } \\
\text { deflection } \\
{[\mathrm{mm}]}\end{array}$ \\
\hline 0 & 0 & 100 & 0 & 1,987 \\
\hline 1 & 60 & 100 & 0 & 2,773 \\
\hline 2 & 60 & 120 & 15 & 2,684 \\
\hline 3 & 60 & 120 & 30 & 2,615 \\
\hline 4 & 60 & 80 & 15 & 2,869 \\
\hline 5 & 60 & 80 & 30 & 2,954 \\
\hline
\end{tabular}




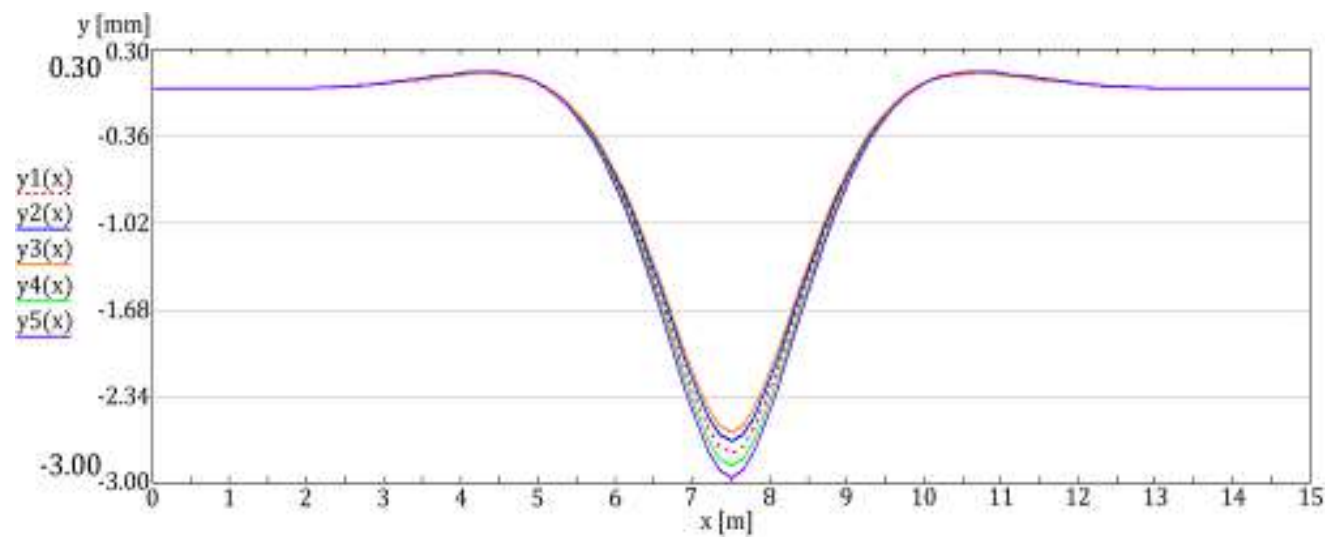

9. Plot of the maximum deflection of the rail $60 \mathrm{E} 1$, depending on the stiffness of the track support in the section adjacent to the contactless area, with the length of about $60 \mathrm{~cm} \mathrm{[22]}$

(Designations as in Table 4.1.)

Computational analysis carried out in a local variation in the stiffness of the support rail in the section adjacent to contactless area (Fig. 9) shows that:

- the increase in the stiffness of the support on the short length of $15 \mathrm{~cm}$ allows only $3.2 \%$ reduction in the deflection of rail,

- while the increase in the rigidity of the support on the length of $30 \mathrm{~cm}$ decreases deflection by $5.7 \%$,

- otherwise, i.e. when the reduction of the rigidity over the length of $15 \mathrm{~cm}$ causes the increase in deflection by $3.5 \%$, while the reduction in the support rigidity no the length of $30 \mathrm{~cm}$ results in the $6.5 \%$ increase in rail deflection.

The obtained results indicate that the increase in rigidity of the ground susceptibility within the area with no contact between the ground and the track, cannot improve the work of rail track. It causes only a slight decrease in the deflection of the rail, with the order of a few percent. Thus, particularly important are new experimental methods for detecting defects in the rail/track, for example, those using wavelet transformation in detecting defects in the continuous beam elastically supported [21].

\section{Conclusions}

The carried out analysis can state that:

1. The analysis shows the change in working conditions of rail as a result of imperfections arising during the exploitation of contactless rail track.

2. In the case of resting railway track on local unevenness of ground it is observed a change in the conditions of the track support. The assumed single unevenness of ground caused that the length of the segment with no contact between the track and the ground is $4.64 \mathrm{~m}$ (see Fig. 3a). However, in the case of three unevenness of the ground, an increase in the length of contact between the track and the ground to the $5.283 \mathrm{~m}$ occurs (Fig. 3b), which affects particularly the performance of track in a horizontal plane during high temperature by weakening transversal resistance. The analysis reflects the impact of deformation of railway track on increase in the length of contact zone. In addition, deformable ballast substrate and rail track cause e.g. a progressive disorder in the railway rolling stock as a result of emerging ground unevenness (Fig. 4).

3. Analysis of the additional deflection of the rails depending on the type and length of the zone with no contact indicated the advantageous greater rigidity of the rail in the vertical plane and reduction in the length of the contactless zone. 
4. Analysis of the impact of changes in compressive force in the track rail (Fig. 6) showed that the track deflection is greater for the one-parameter substrate and increases with the growth of axial force exerted on the railway track.

5. The computational analysis of the local change of stiffness of rail support in the section adjacent to the contactless area (Fig. 9) shows that the increase in rigidity on sections adjacent to the contactless zone is not obvious source of improving the working rail track. This results in only a slight decrease in the deflection of the rail, with the order of a few percent. The reduction in the stiffness of the sections immediately surrounding the zone with no contact occurring in the real railway track further increases the deflection of the rail.

\section{Source materials}

[1] Bałuch H.: Sposoby wyznaczania charakterystyk podłoża kolejowego. Problemy Kolejnictwa z. 39, Warszawa, WKi乇 1967,

[2] Bednarek Wł.: Local unevenness of lengthwise profile influence on stability conditions of continuous welded rail track. Foundations of Civil and Environmental Engineering, Poznań University of Technology, No. 10, 2007,

[3] Bednarek Wł.: The analysis of the influence of variable roadbed stiffness and support of railway sleeper on its work. Foundations of Civil and Environmental Engineering (FCEE), Poznan University of Technology, No. 13, 2010,

[4] Bednarek Wł.: Analiza wpływu podłoża i sposobu podparcia na pracę podkładu kolejowego. Archiwum Instytutu Inżynierii Ladowej (Archives of Institute of Civil Engineering), Poznań University of Technology, 9/2011,

[5] Bednarek Wł.: Wpływ pionowych odkształceń nawierzchni i podtorza na pracę toru bezstykowego. Seria Rozprawy Nr 506, Wydawnictwo Politechniki Poznańskiej, Poznań 2013, ISSN 0551-6528,

[6] Bednarek Wł.: Wybrane zagadnienia współpracy nawierzchni z podłożem podczas eksploatacji bezstykowego toru kolejowego, Przegląd Komunikacyjny nr 10/2014,

[7] Bednarek Wł.: Determination of foundation coefficients for a 2-parameter model on the basis of railway sleeper deflection. International Conference of Continuous Media with Microstructure II, Łagów, 2015

[8] Bednarek Wł.: Zagadnienia powstających pionowych nierówności w eksploatowanym torze kolejowym, Przegląd Komunikacyjny 2/2016, rocznik LXXI,

[9] Czyczuła Wł.: Wpływ niejednorodności podłoża szynowego na dodatkowe ugięcia szyny pod obciążeniem użytkowym, Drogi Kolejowe nr 5/1991,

[10] Czyczuła Wł.: Eksploatacyjna stabilność drogi kolejowej. Monografie Politechniki Krakowskiej, nr 126, Kraków 1992,

[11] Drozdziel J., Sowiński B., Szulczyk A.: Equivalent track stiffness determination. International Virtual Journal for Science, Techniques and Innovations for Industry, 2011,

[12] Huber M. T.: Pisma. Zagadnienia kolejowe. Tom III, dział VIII, PWN, Warszawa, 1957 ,

[13] Lewandowski R., Świtka R.: Zginanie belek na sprężysto-plastycznym podłożu Winklera z więzami jednostronnymi. Archiwum Inżynierii Lądowej - Tom XXXIV, Z. $1 / 1988$,

[14] Madej J.: Teoria ruchu pojazdów szynowych, Oficyna Wydawnicza Politechniki Warszawskiej, Warszawa 2004,

[15] Mączka J., Szefer G.: Belka Timoshenki przedziałami spoczywająca na podłożu typu Wieghardta. Archiwum Inżynierii Lądowej, tom XVII, z. 1/1971, 
[16] PKP: Id-1 (D-1) Warunki techniczne utrzymania nawierzchni na liniach kolejowych, Warszawa 2005 r. z późn. zmianami.

[17] Siewczyński Ł.: Zagadnienia wspólpracy nawierzchni kolejowej $\mathrm{z}$ podtorzem gruntowym. Wydawnictwo Politechniki Poznańskiej, seria Rozprawy nr 66, Poznań, 1974 ,

[18] Skrzyński E.: Wpływ dużego obciążenia ruchem oraz zwiększonych szybkości pociągów na pracę podtorza. Problemy Kolejnictwa, nr 67, Warszawa 1975,

[19] Szumierz W.: Analiza utraty kontaktu prostego toru bezstykowego z podłożem. Archiwum Inżynierii Lądowej, tom XIX, z. 2, 1973,

[20] Szumierz W.: Wpływ odkształceń podłoża górniczego na pracę podkładu betonowego. Drogi Kolejowe nr 4/91,

[21] Ziopaja K. Guminiak M: Zastosowanie dyskretnej transformacji falkowej w wykrywaniu uszkodzeń w belkach ciągłych podpartych sprężyście. Archiwum Instytutu Inżynierii Lądowej, Poznań 2015,

[22] Zydorek M.: Analiza wybranych zagadnień współpracy bezstykowego toru kolejowego podczas znacznej zmiany jego kontaktu i podparcia z podłożem podsypkowym. Praca magisterska (pod kierunkiem Wł. Bednarka), Poznań 2016 (maszynopis). 